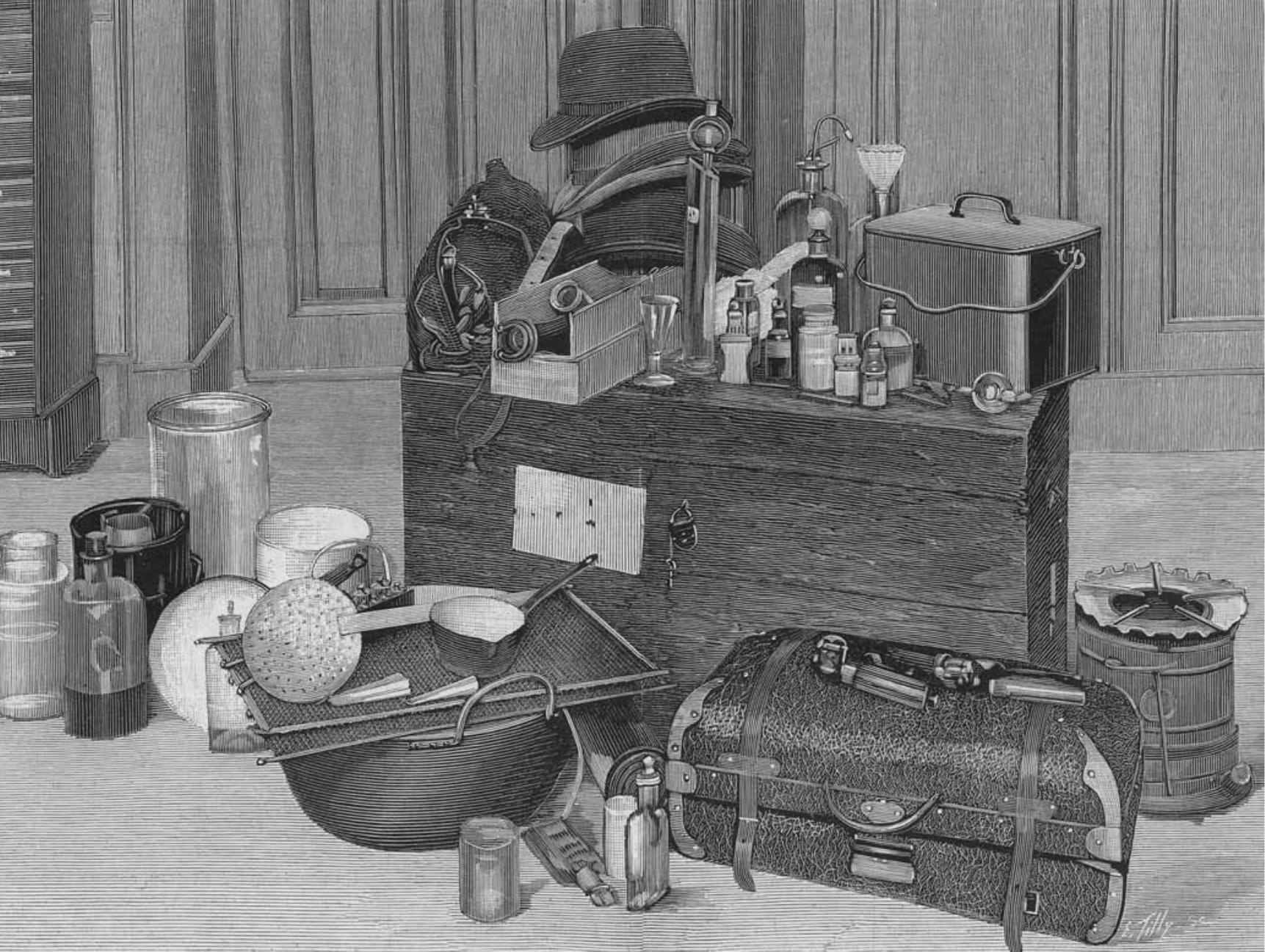

Materiaal dat aangeslagen werd door de politie na de aanhouding van de 'bommenwerpende' anarchist Ravachol (Uit: L'Illustration, 30 april 1892) 


\section{Hedendaags anarchisme in Nederland en Vlaanderen}

Andreas Faes, licentiaat geschiedenis UGent

Het anarchisme is een ideologische stroming die zijn hoogtepunt kende aan het einde van de 19e eeuw. Sindsdien is het voor veel uitdagingen komen te staan, waar niet altijd adequaat op gereageerd werd. Aan de hand van een casus, de Pinksterlanddagen (PL) in Appelscha, wordt de evolutie van het anarchisme in microperspectief bekeken. Geconfronteerd met de internationale context, zien we hoe het anarchisme in de jaren 1960 eindelijk herstelt en voor een ideologische vernieuwing zorgt.

Beeldvorming uit de 19e en 20e eeuw omtrent het anarchisme en de anarchist heeft ervoor gezorgd dat deze begrippen - verkeerdelijk - synoniem werden voor terrorisme, iconoclasme, vandalisme, goddeloosheid en marginaliteit. Een eenduidige en afdoende definitie van hét anarchisme is nog niet gegeven, maar ze zou in elk geval het begrip vrijheid bevatten en een afkeer van elke vorm van autoriteit, die de persoonlijke vrijheid en ontplooiing enkel belemmert. De Staat, symbool van deze autoriteit, wordt bestreden. Dit gebeurt veelal op pacifistische wijze, al gingen enkelingen over tot terroristische acties om de anarchistische eisen kracht bij te zetten. Alhoewel wordt uitgegaan van een destructief beginsel (de afbraak van de Staat), laat het anarchisme zich vooral kennen door de constructieve voorstellen voor een vrije toekomstmaatschappij na die afbraak. In concreto wordt een vorm van communisme voorgestaan (soms anarchocommunisme genoemd) op grond van menselijke solidariteit, met gemeenschappelijk bezit van eigendom en socialisatie van de productie. ${ }^{(1)}$ 
Het anarchisme dat uit de literatuur naar boven komt, is steevast het anarchisme uit de 19e eeuw, of begin 20e. Quasi reglementair verwatert de gedetailleerdheid van de historische beschrijvingen vanaf de Eerste Wereldoorlog en valt de geschiedschrijving na de Tweede Wereldoorlog over het onderwerp volledig stil. Niet zonder reden, want in de praktijk heeft het anarchisme in eerstgenoemde periodes zijn hoogtepunt gekend.

In 1871 werd het Algemeen Nederlands Werklieden Verbond (ANWV) opgericht in Nederland. De oprichters voelden zich niet meer thuis in de Internationale en zetten zich er tegen af. Al is haar invloed op de arbeiders gering geweest, toch wordt deze organisatie gezien als een van de wegbereiders van de sociaaldemocratische partijen in Nederland. ${ }^{(2)}$ De grote doorbraak van het anarchisme kwam in 1882, paradoxaal genoeg met de oprichting van de Sociaal-Democratische Bond (SDB). Deze politieke formatie luidde immers de opgang in van de charismatische ex-dominee Ferdinand Domela Nieuwenhuis. ${ }^{(3)}$ Ontgoocheld door zijn ervaring in de Tweede Kamer (als eerste Nederlandse socialist), bekeerde hij zich tot het anarchisme en zijn antistaatsdenken. Als voorman kon hij voor het Nederlandse anarchisme doen waar niemand in België (of Vlaanderen) in slaagde: een slagkrachtig front vormen gebaseerd op interne samenwerking. Met zijn dood in 1919 zakte het Nederlandse anarchisme finaal als een kaartenhuis in elkaar ${ }^{(4)}$ en zou nooit meer de grandeur van de jaren 1891-1903 kennen.

Vlaanderen heeft, in tegenstelling tot Wallonië waar het anarchisme (met name in Luik) prominent aanwezig was, nooit veel betekend op het internationale anarchistische vlak. Afgezien van een belangrijke kern in Mechelen en de oprichting van een dissidente universiteit te Brussel, de Université Nouvelle, heeft het Vlaamse anarchisme geen krachtdadige acties kunnen ontplooien. ${ }^{(5)}$ César De Paepe, later medeoprichter van de Belgische Werklieden Partij (BWP) nota bene, benaderde de functie van Vlaams libertair boegbeeld het best. Zijn Rede van Patignies uit 1863 is de beste synthese van het Vlaamse anarchisme: "Alleen de afwezigheid van elke regering, van iedere macht belichaamde de volledigste vrijheid en gelijkheid. De Paepe wilde de anarchie zien groeien door de logica van de geschiedenis zelf. Er was geen weg naast. Socialistische revolutie is in die zin niets anders dan een progressieve vernietiging van de macht ten voordele van de vrijmaking van het individu." (6) $\mathrm{Al}$ had het nooit een grote aanhang, het anarchisme leefde ook in Vlaanderen.

\section{Het traditionele anarchisme: bloei en verval}

$\mathrm{Na}$ een periode van relatieve bloei in de 19e eeuw, geraakte het internationale anarchisme vanaf de periode 1914-1918 in vrije val. Enerzijds werd door het oorlogsgeweld en de bezetting van vele landen politieke actie bemoeilijkt: kreten vanuit het libertaire kamp gingen verloren in het geschreeuw om een einde aan de oorlog. Anderzijds was er ook binnen het anarchisme een doctrinaire discussie aan de gang, die een (eerste) interne scheuring zou teweegbrengen. Het conflict werd gesymboliseerd door de ruzie tussen 
de libertaire kopstukken Kropotkin en Malatesta, die een tegengestelde stelling innamen tijdens de oorlog. Kropotkin tekende immers het Manifest der Zestien, een openlijk pleidooi voor deelname aan de oorlog aan de zijde van de geallieerden. ${ }^{(7)}$ Malatesta had in 1915 al het antimilitaristische manifest L'Internationale anarchiste et la Guerre getekend, dat stelde dat deelname aan de oorlog geenszins een zaak van anarchisten mocht zijn. Al was hij geen pacifist pur sang, hij was tegen deze oorlog omdat het er een was tussen verschillende natiestaten en hij nooit een emanciperende functie zou hebben. Deze eerste uitdaging liet de verschillende nationale anarchistische bewegingen, Spanje buiten beschouwing gelaten wegens zijn neutraliteit, verzwakt achter.

De Russische Revolutie van 1917 bleek de tweede struikelsteen voor het anarchisme. Initieel werd de oorlogsmoeheid van de sovjets onterecht ingeschat als de kiem van een revolutionaire geest. Vele anarchisten, onder wie ook weer Kropotkin, namen dan ook openlijk deel aan de revolutie. Al snel werd duidelijk dat de sovjets ingeschakeld werden als instrumenten van de politiek van de bolsjewieken, en bijgevolg verlieten veel anarchisten Rusland. De aantrekkingskracht van het werkbare communisme van Lenin en Stalin bij de arbeiders, bleek daarbovenop een krachtige uitdaging voor het anarchisme.

\section{De Pinksterlanddagen: anarchistische traditie in Nederland}

In de jaren 1920 was het naoorlogse optimisme aanleiding tot de oprichting van een specifieke jongerenorganisatie: het Vrije Jeugd Verbond (VJV). Als een van de belangrijkste woordvoerders van de Nederlandse anarchistische jeugdbeweging, opperde Jo de Haas in 1923 al het idee om een manifestatie te organiseren ter mobilisatie van de jeugd tegen het militarisme: "Wij roepen op, alle jongeren die voor de VRIJHEID der MENSHEID willen vechten.” (8) Op een terrein in Amersfoort (Utrecht) vond op 8 juni 1924 de eerste Pinkstermobilisatie plaats, het begin van een lange traditie. Deze bijeenkomst stond geheel in het teken van de dienstweigering en het antimilitarisme, hetgeen gezien de geschiedenis van het Nederlandse anarchisme met zijn buitenmatige focus op antimilitarisme en de voorbije oorlog, niet onlogisch was. De eerste mobilisatie trok enkele honderden bezoekers uit het hele land. In diezelfde maand werd in het Friese Appelscha een gelijkaardige mobilisatie op poten gezet voor anarchisten uit de drie noordelijke Nederlandse provincies Drenthe, Groningen en Friesland. De reden daartoe was veeleer praktisch dan ideologisch, het was voor de arbeiders uit deze streken moeilijker om zich naar Utrecht te begeven. Deze Revolutionaire Anti-Militaristische Landdag kende een grotere opkomst dan zijn algemeen Nederlandse tegenhanger. ${ }^{(9)}$

Binnen het VJV werd na enkele jaren van succesvolle acties de tegenstelling duidelijk tussen de uitgesproken anarchistische groep die zich rond het blad De Moker schaarde en de groep met een bredere oriëntatie rond het blad De Kreet der Jongeren. ${ }^{(10)}$ In 1926 scheidde de gematigde strekking zich af van het VJV en richtte het Verbond van Op- 
standige Jeugd (VOJ) op. De Mokergroep wordt gezien als een van de merkwaardigste zelfstandige arbeidersjeugdbewegingen die Nederland ooit gekend heeft. Bloeiend van 1924 tot 1928 en met 500 aanhangers, deed die beweging overal van zich spreken door haar propagandistisch slimme vondsten en haar extreme opvattingen. Zij was een hevige voorstander van directe actie en choqueerde graag: "Een ieder moet weten dat wij gezagloze, goddeloze, haveloze en het liefst werkloze proleten in deze samenleving zijn, en dat we van hun religieuze ethische gedoe ook geen liefhebbers zijn." (11)

Alhoewel er nu twee organisaties waren, VJV en VOJ, bleef de Pinkstermobilisatie een gezamenlijke onderneming. Onderlinge wrevel zorgde echter voor een onhoudbare situatie die in 1927 explodeerde toen beide partijen tegelijkertijd en op hetzelfde terrein, een aparte Pinkstermobilisatie wilden organiseren. Vanaf dan werden twee afzonderlijke mobilisaties georganiseerd en dit bleef zo tot aan de vooravond van de Tweede Wereldoorlog. In Appelscha evenwel, waar de noordelijke beweging haar thuishaven had, werd besloten tot de aankoop van een eigen terrein, waar - met een onderbreking tijdens de Tweede Wereldoorlog - sindsdien elk jaar de Pinksterlanddagen (PL) zouden plaatsvinden. ${ }^{(12)}$ Zo ontstond het terrein Tot Vrijheidsbezinning (TVB) en de anarchistische traditie in de Noord-Nederlandse provincies was 'veiliggesteld'.

\section{Grenzen aan de anarchie: 1936-1945}

De aanhang van het anarchisme slonk gevoelig tijdens het interbellum, voornamelijk omdat een grote groep anarchisten zich tot de vakverenigingen ging richten als wapen tegen het kapitalisme en een nog grotere groep zijn heil zocht in het communisme. Op dat moment was Spanje nog het enige echte bastion van het anarchisme; de Eerste Wereldoorlog had de groeperingen daar relatief ongemoeid gelaten. Al voor de roemruchte Spaanse Revolutie kende Spanje een levendige, rijke anarchistische (of op z'n minst libertaire) traditie: het Andalusische platteland was opgedeeld in zelfstandige collectieven en de nationale vakvereniging had meer dan een miljoen leden. Die dubbele grondslag van het Spaanse anarchosyndicalisme, industrieel en landelijk, had de richting bepaald van het libertair communisme waarop het zich in twee enigszins afwijkende opzichten beriep: het ene gericht op de commune, het andere op het syndicalisme. ${ }^{(13)}$ Toen in 1936 het Volksfront de verkiezingen won, werd dit in Spanje en elders aanzien als het begin van de sociale revolutie. De regeringsdeelname van de anarchisten bleek het kritieke punt voor het slagen van de revolutie. Het einde van Spaanse revolutie in 1939 was een zware desillusie voor de Spaanse anarchisten en de doodsteek voor het internationale anarchisme. Het had het anarchistische kamp verder verdeeld tussen principiële antimilitaristen en pragmatici die geweld in de Spaanse context als opportuun zagen. Nederland kende ook die tweedracht: de onenigheid tussen de anarchisten omtrent eventuele deelname aan de oorlog zou nog jaren voortduren. De twee meest prominente antimilitaristische verenigingen, IAMV en IAMB, 
kregen splinterbewegingen en de werking van beide organisaties raakte volledig verlamd.

De Tweede Wereldoorlog was voor het traditionele anarchisme een beproeving die het nooit meer volledig zou te boven komen. Het politieke klimaat in België en Nederland werd al snel gekenmerkt door onderdrukking van andersdenkenden, niet in het minst van anarchisten. De oorlog verlegde de prioriteiten van veel mensen die in 'de beweging' actief waren. Van ageren was nog amper sprake, uit vrees voor represailles en omdat overleven in de barre oorlogssituatie primair was. De beweging viel echter niet volledig stil. Enkelingen, zoals Jo de Haas bleven het anarchistische gedachtegoed te allen tijde volledig trouw. Alhoewel het anarchisme als beweging nooit een krachtige verzetsbeweging heeft opgeleverd, tenminste niet vergelijkbaar met de communistische verzetspraktijken, kan wel gesteld worden dat individuele anarchisten actief bleven als verzetsfactor, veelal niet vanuit georganiseerde anarchistische hoek, maar wel uit persoonlijk verzet geïnspireerd door het anarchisme. Dit uitte zich hoofdzakelijk in hulp aan behoeftigen, zoals Duitse vluchtelingen, joden en onderduikers. ${ }^{(14)}$

$\mathrm{Na} 1945$ bestond het anarchisme dus nog, zij het enkel in naam en geleid door de oude garde van voor de oorlog, omdat de nieuwe generatie - gedesillusioneerd door de oorlog - de teugels niet had overgenomen. Van vernieuwing was de eerste jaren geen sprake, enkel consacratie van het bestaande was van tel. Ook op het terrein TVB in Appelscha was dit duidelijk zichtbaar: de bijeenkomsten op Pinksteren waren van strijdbaar naar gezellig geëvolueerd en de groep achter de landdagen geraakte meer en meer versplinterd door onderlinge vetes. Enkel nog in naam was het een libertair weekend.

\section{Prille tekenen van verandering}

Het zou tot eind jaren 1950 duren voor het Nederlandse anarchisme zachtjes uit zijn slaap gehaald werd. In een aantal vooraanstaande tijdschriften klonk schoorvoetend de oproep tot intellectuele herbronning en tot verhoogde jongerenparticipatie. IJdele hoop zo bleek de komende paar jaren. De ommekeer voor het anarchisme - en in feite voor de hele linkse wereld - kwam pas midden jaren 1960, met 'het fenomeen Provo'. De provobeweging bespreken is geen evidentie. ${ }^{(15)}$ Meer dan iets vatbaars, was het een beeld van iets, een 'image' zoals ze zelf volhielden. Er werd geageerd tegen een vijand die steunde op centralisatie, militarisme en bezit: deze vijand provoceren - vandaar ook de naamgeving - was de reactie van deze groep jongeren. Sommige auteurs maken de vergelijking met De Mokerbeweging van de jaren 1920, omdat ze dezelfde hoofdkenmerken gemeen hadden. Provo maakte echter veel beter en handiger gebruik van de nieuwe media en bereikte aldus een veel groter publiek. ${ }^{(16)}$

Op ideologisch vlak stond ze een vernieuwing van het anarchisme voor, zoals Roel van Duyn - de ideoloog van Provo - boud stelde: "Toen begon ik eraan te denken een nieuw tijdschrift 
ANTI AUTORITAIRE OPPOSITIE NU BEN KONGRES TE APPELSCHA WR OP 16 \& 17 MEI 1970 OVER: BUIT EN PARLEMENTAIRE AKSIE, KOM MUNE, ASSOSTATIES, KRESJES, OR ANJE VRYSTAAT, STUDENTENVERZ RT, DOLLEMINA, ETC...*AANVANG 3 UUR * MET FILMS \& O.A. TON B EGTIEN, OTTO BOETES, BOEL VAN DUYN * DISKUSSLEMAP FL.2,- OP GIRO 1756680 - H.ZUTDEMA.D.HAAG INL. 10. BANKASTR. 145. \& 05169 $458 \circ K$ A B O V T E B ० KONGRES NU ANT AUTORITAIRE OPPOSITIE 
op te richten, dat het anarchisme in een voor deze tijd aantrekkelijke vorm moest gieten." (17) Eerst en vooral uitte zich dat in een resoluut afwijzen van de oude marxistische tegenstelling bezittende klasse - bezitloze klasse (de antagonistische burgerij versus proletariaat) en deze te vervangen door de tegenstelling provotariaat - de intellectuele elite, de provo's in essentie - tegenover het klootjesvolk (de domme massa). Naar anarchistische traditie in Nederland, lag ook in deze nieuwe variant een grote nadruk op het geweldloze, het pacifistische (cf. het gebruik van rookbommen, dat enerzijds schadeloos is, maar anderzijds het image heeft - en de naam - van een bomactie). Provo introduceerde ook voor het eerst de ecologie in de praktijk van het anarchisme en Van Duyn probeerde daar een theoretische grondslag voor te vinden. De kiemen voor een nieuw anarchisme werden gezaaid in de twee jaar dat Provo bestond. De haast mythische gebeurtenissen van mei '68 versterkten enkel het proces dat in Nederland door Provo op gang werd gebracht

\section{Appelscha beeft: de PL '70}

Het duurde tot 1970 voor de veranderingen op maatschappelijk en links-intellectueel gebied het terrein te Appelscha bereikten, maar toen sloegen ze in als een bom. Een grootschalig anti-autoritair congres werd georganiseerd, met - op dat moment - klinkende namen als Roel Van Duyn (Provo), Ton Regtien (studentenactivist) en Otto Boetes (anarchist). Enkel actuele onderwerpen werden dat jaar op het programma gezet, zoals de antiautoritaire opvoeding, Dolle Mina, het buitenparlementarisme en het NewBabylonproject van Provo. ${ }^{(18)}$ Linkse jongeren waren massaal aanwezig. Niet enkel het anarchisme was er vertegenwoordigd, er waren ook marxisten, marxistisch-leninisten, trotskisten, sociaaldemocraten, Kabouters, pacifisten, Nederlandse Black Panthers en mensen uit verschillende plaatselijke actiegroepen. Het belang van dit congres was tweeledig: vooreerst bezegelde het de verzoening tussen de Vrije Socialisten van het westen van Nederland en het noordelijk gewest, die nog altijd kampten met historische onenigheden. ${ }^{(19)}$ Ten tweede waren er vierhonderd actieve deelnemers, iets wat na de oorlog nog niet was voorgevallen.

In de nasleep van deze PL werd een nieuw anarchistisch samenwerkingsverband opgericht. De Federatie van Vrije Socialisten (FVS) - geïnspireerd door de gelijknamige federatie van Domela Nieuwenhuis, die een zeer korte geschiedenis kende - werd gesticht in het weekend van 1 en 2 mei 1971, ruwweg een maand voor de PL'71. Het einde van de federatie kwam al na vijf jaar in zicht: in 1975 was zij al lang geen bindmiddel meer voor de anarchistische landelijke beweging en - een laatste poging tot reanimatie ten spijt in 1978 - ze stierf dan ook een stille dood in 1979. Al snel werd ze vervangen door een nieuwe Anarchistische Federatie (AF), met een internationaal secretaris, maar ook deze zou dienen om contacten in stand te houden en nooit in staat zijn om een ware koepel te vormen.

Affiche van PL '70 (Archief Appelscha, postercollectie) 
Na 1970 kwamen jaren waarin door onderlinge samenwerking tussen jong en oud de verschillende landdagen vorm werd gegeven. Thematisch is dit duidelijk merkbaar: er is een symbiotische relatie tussen traditionele onderwerpen en 'nieuwe' onderwerpen. Maar geleidelijk aan zal de oudere generatie de organisatie weer naar zich toetrekken en zullen de nieuwe groepen uit 1970 ook deel gaan uitmaken van het anarchistische establishment. De dreiging van verstening, nog maar een decennium na de 'grote vernieuwing', was op dat moment meer dan reëel. Het was dus hoog tijd voor een nieuwe golf van verjonging. Die kwam er na de landdagen van 1986. Met een ambitieus congres, Anarchistische strategie en samenwerking, werd aansluiting gezocht bij de poging tot actualisering van het anarchisme van 1970. Alhoewel dit congres minder spraakmakend was, bleef het niet zonder betekenis. Ook dan zag een grotere overkoepelende organisatie het licht: het Landelijk Anarchistisch Overleg (LAO), met als doel de contacten tussen verschillende anarchistische werkgroepen te verstevigen en het verdiepen van de samenwerking op landelijk niveau. Het LAO (en zijn opvolger LAS) was echter ook een kort lot beschoren, omdat het te weinig eigen activiteiten ontplooide en nooit voorbij het praatbarakstadium geraakte. ${ }^{(20)}$

Verjonging is dus geen eenmalige zaak binnen het anarchisme, maar een - eigenlijk vanzelfsprekende - cyclische beweging, die zich onafgebroken heeft doorgezet sinds het ontstaan van de doctrine, de periode 1945-1960 uitgesloten. Een ideologie heeft immers continu nieuwe impulsen nodig vanuit jonge hoek wil ze van tel blijven in een maatschappij die continu verandert. Waar het anarchisme in de periode tussen 1937 en 1965 ter plekke is blijven trappelen, hetgeen de enorme terugval van zijn 'populariteit' verklaart, heeft het door een vernieuwde jongerenparticipatie een deel van zijn aantrek kunnen terugwinnen, met een actualisering van het anarchisme tot gevolg.

\section{Nederlands versus Vlaams anarchisme}

De Nederlandse libertaire traditie eind 19e eeuw was veel rijker dan de Vlaamse en dit had een aantal specifieke oorzaken. Vooreerst was er de levensbeschouwelijke achtergrond. Het calvinisme mocht dan wel openlijk verworpen worden door het anarchisme, toch was het een inherent deel van de dagdagelijkse realiteit in het $19 \mathrm{e}$-eeuwse Nederland. Alhoewel atheïsme een logisch gevolg was van (of basis voor) het anarchisme, was er toch een nauwe band tussen de predikanten en het Nederlandse anarchisme. Veel voormannen - Domela Nieuwenhuis, De Ligt, Schermerhorn - hadden een voorgeschiedenis in de protestantse kerk. ${ }^{(21)}$ De basisideeën bleven dan ook, ontdaan van hun religieuze betekenis, voortbestaan in het 'traditionele Nederlandse anarchisme'. Omdat ascetisme altijd al belangrijk was in religieus-calvinistisch opzicht, werd alcoholisme een groot strijdpunt voor zowel de anarchistische als de bredere socialistische beweging, omdat het proletarische zelfbewustzijn aldus werd belemmerd. Immers, enkel door middel van een heldere geest 
konden heldere daden gesteld worden die de weg naar de revolutie vrijmaakten. Alcohol oefent een externe invloed uit op het individu en het veroorzaakt de onderwerping van de geest: onaanvaardbaar voor anarchisten. Er werden dan ook verschillende organisaties ter bestrijding van het alcoholisme opgericht. De bekendste was de ANGOB (Algemene Nederlandse Geheelonthouders Bond), waar verschillende anarchistische voormannen zich voor hebben ingezet. Daartegenover stond het bourgondische klimaat van Vlaanderen. Alcohol was er nooit het pijnpunt - althans, wat de sociale bewegingen betreft; vanzelfsprekend was alcoholisme een sociaal probleem in Vlaanderen - dat het in Nederland vormde. Nog andere factoren hebben de verspreiding van het anarchisme in Nederland bevorderd. De traditie van het antimilitarisme was er al sinds lang. Zoals Constandse het verwoordt: "Men mag niet vergeten dat het land, dat sinds 1815 buiten alle Europese oorlogen was gebleven, niet kon bogen op roemlijke landstrijdkrachten en des te meer op de wens [om] neutraal te blijven. Nergens was het anarchisme zo verweven met de strijd tegen de oorlog als in Nederland.” (22) In België werden - om op de zaken vooruit te lopen - antimilitarisme en dienstweigering pas een prominent agendapunt in de jaren 80 van de 20 e eeuw.

Naast de verschillen in ideologie, is het van belang deze in de beweging aan te tonen. Nederland ontwikkelde "een van de origineelste anarchistische bewegingen in Europa" (23) met vele federaties en organisaties. In Vlaanderen waren 'groupusculen' veeleer de regel. Dit had vooral te maken met het ontbreken van leidersfiguren. Nederland had een veel grotere schare van intellectuele anarchistische voormannen: Domela Nieuwenhuis als belangrijkste, daarnaast Bart de Ligt, Jo de Haas, Anton Constandse enz. Daarnaast had Nederland ideologen van het anarchisme onder wie Clara Meijer Wichmann, die als juriste diepere inzichten in de relatie anarchisme/recht aanbracht. ${ }^{(24)}$ In België lag het zwaartepunt van de beweging in Wallonië en Franstalig Brussel. Voor Vlaanderen was het César De Paepe die een theoretische invulling gaf aan het Vlaamse anarchisme. Het is dus opportuun of op z'n minst zinnig, gezien het verschil in theoretische invulling en infrastructuur, om een verschil aan te duiden tussen de nationale 'varianten' van Nederland en Vlaanderen.

$\mathrm{Na}$ de Tweede Wereldoorlog viel de interesse voor het anarchisme als ideologie terug, zowel in België, Nederland als over heel de wereld. Het kwam in beide landen terug naar voren in de jaren 1960 en 1970, zij het veranderd. Onder invloed van de ideeën van de 'New Left' transformeerde de ideologie en werden de verschillen tussen de landelijke varianten steeds kleiner. Nieuwe inhoudelijke onderwerpen kwamen aan bod: ecologie, jongerenverzet, anarchofeminisme en sociaal onrecht. Globaal gezien blijft er van de grote verschillen op ideologisch vlak nog maar weinig over. In dat opzicht is de tendens tot globalisering van groot belang: met de opkomst van verschillende communicatiemiddelen, verschuift het traditionele 'postbusanarchisme' naar een anarchisme dat minder gebonden is aan kleinschalige communicatie. Een internationalistische kijk op de zaken is hier een rechtstreeks gevolg van. Vandaag lijkt het dus nog moeilijk vol te houden dat 
3/mm hoelang gaan we nog met ons kloten laten spelen kameraad?
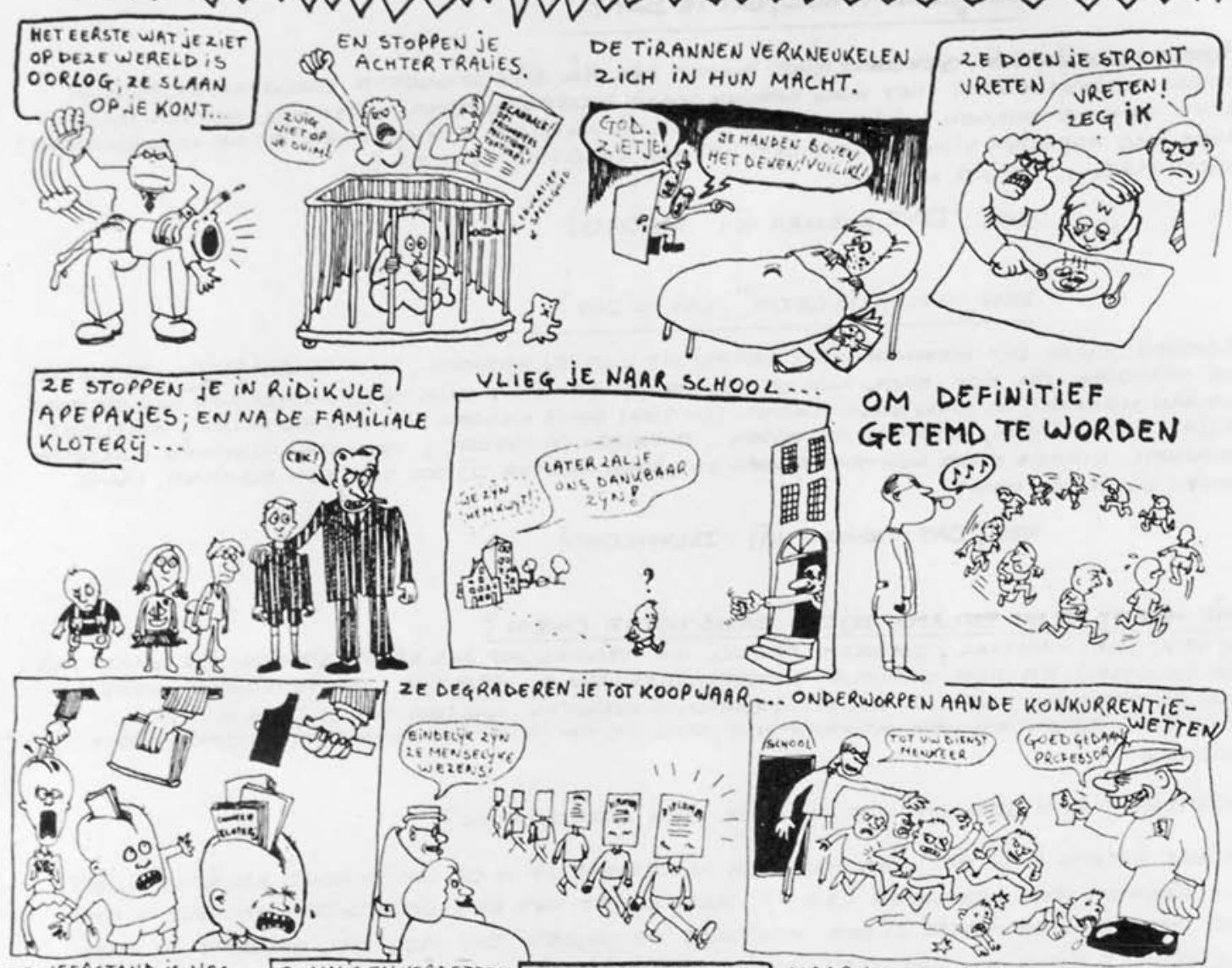

DE WEERSTAND IS NOG SOMMIGEN UER ZETTEN
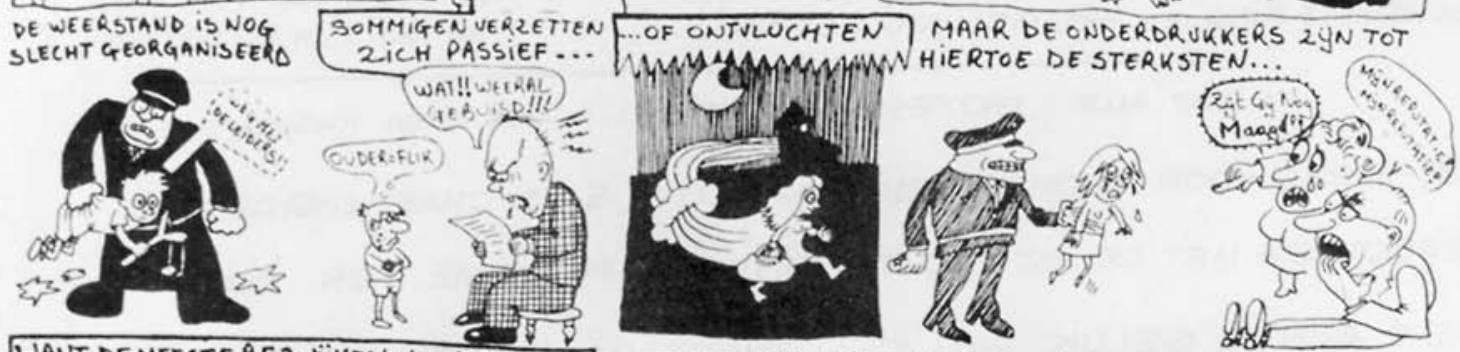

WANT DE MEESTE BE2 WŸKEN VOOR OE POEN

-. EN 20 VLUG MOGELGK IDENTIFICEREN 2 E ZICH MET DE
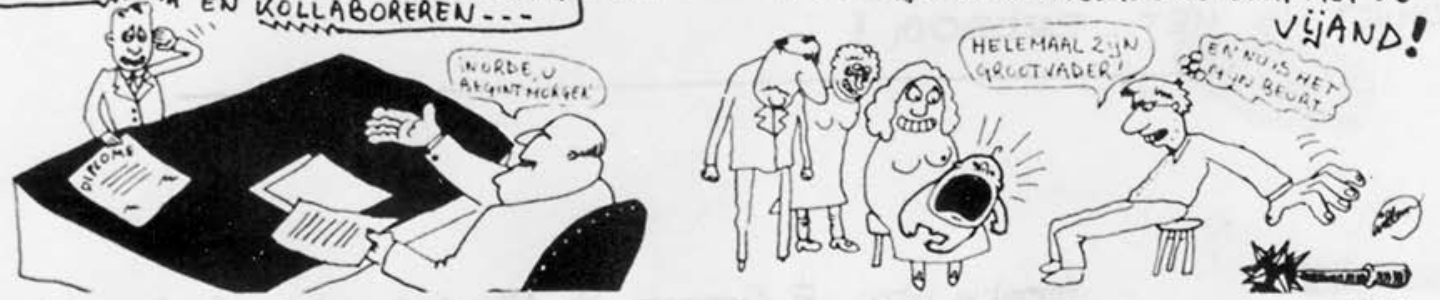

KAMERADEN, BREEK DE KRINGLOOP VAN HETGE2AG ? STOP MET HIËRARCHISEREN, GEHOORZAMEN, KAPITULEREN ? ? 
er inherente verschillen zijn tussen het Belgische en Nederlandse anarchisme, wat de ideologie betreft. Verschillen in beleving van het anarchisme zijn er, gezien de verschillende culturele contexten, wel nog.

\section{Hedendaags anarchisme?}

Tezamen met een nieuwe generatie, veranderde ook de samenstelling van de anarchistische (of libertaire) groepen danig. Traditioneel werd uit een arbeidersomgeving gerekruteerd, maar dit patroon sloeg om tijdens de jaren 1970. Het anarchisme werd een zaak van jongeren uit de middenklassen. Zoals een enquête in het anarchistische tijdschrift Freedom uit 1962 aantoont, behoorde enkel $15 \%$ van de zichzelf anarchistisch noemende jongeren tot de traditionele groepen van arbeiders en boeren; van de $85 \%$ van de witteboordenbevolking was de grootste groep actief in het onderwijs, als student of als docent. ${ }^{(25)}$ Dat dit een heroriëntering meebracht, lijkt een plausibele hypothese. Hoe het ook zij, de sfeer was omgeslagen en een nieuw anarchisme werd geboren uit de as van het traditionele.

Wat decennialang de focus van het Nederlands anarchisme was geweest, het antimilitarisme, werd omgebogen in het kader van een prangender probleem: de verplichte militaire dienst. "Onder totaalweigeren verstaan we de hedendaagse vorm van dienstweigeren, waarbij niet enkel de militaire dienstplicht wordt afgewezen, maar ook (...) de wettelijk voorziene vervangende burgerdienst. Enkel die dienstweigeraars [worden onder deze categorie gerekend] die beide vormen van dienstplicht weigeren op basis van politieke motieven.” (26) De vraag was dus waarom iemand die weigert dienst te nemen in het leger, genoodzaakt was een vervangende dienst te doen, voor een Staat waar ze - in het geval van de anarchisten - tegen ageerden. In essentie bracht burgerdienst mee dat de oppositie gekanaliseerd werd; indirect werd de militaire maatschappij niet verholpen. Kritiek werd dus uitgeschakeld en enkel het geweten en de opvatting van het individu werden in vraag gesteld, niet het militarisme op zich.

Een tweede vernieuwing in het hedendaagse anarchisme betreft het anarchofeminisme, dat kaderde in de algemene tweede golf van het feminisme. Vooral de geschriften van Emma Goldman zijn in eerste instantie duidend voor de richting waarin dit anarchisme zich ontwikkelde. Wat de theoretische onderbouw betreft werd ten eerste het paradigma van het feminisme, 'het persoonlijke is politiek', erkend: deze vrouwen wilden hun eigen normen en waarden ontwikkelen tegenover de vooroordelen en heersende ideeën. Ze wilden zich niet aanpassen aan de heersende mannennormen, die hiërarchie, agressieve concurrentie, zakelijkheid enz. verheerlijken en ze streden voor de afschaffing van de stereotiepe seksuele rollen. Ten tweede vormt het model van de toekomstige maatschappij-inrichting een groot verschilpunt met de 'reguliere' (lees: niet-anarchistische) vrou-

\footnotetext{
Anarchistiche afiche, jaren 1970
} 
WJ, KONING DER BELGEN!

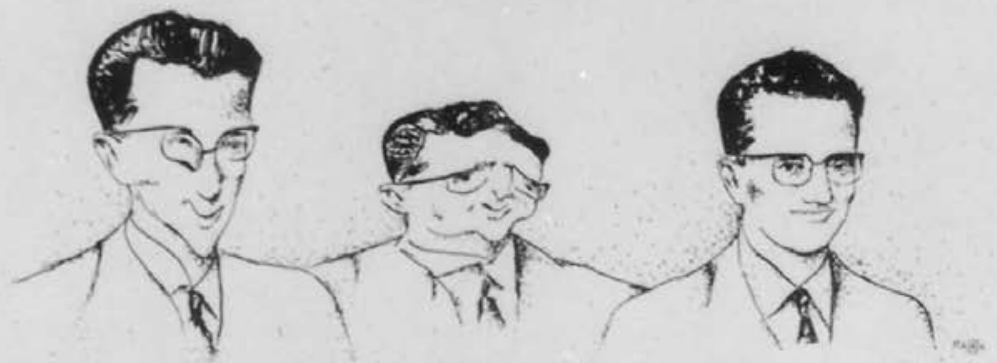

\section{BEVELEN AAN VOLGENDE DISCUSSIES:}

di $12 / 10$ STUC

di $19 / 10$

De VALK

di $26 / 10$

STUC

do $04 / 11$

De VALK

di $09 / \mathrm{II}$

STUC

di $16 / 11$

AUD. VESALTUS

wo $24 / 11$

De VALK

di $30 / 11$

AUD. VESAL TUS

di $07 / 12$

AUD, VESALIUS

di $14 / 12$

STUC
KOMMUNES IN HET PERSPECTIEF VAN MAATSCHAPPELIJKE VERANDEAING m.m.v. kommunes uit Denemarken, Engeland e.a.

DIAEKTE DEMOKAATIE

m.m.v. Michel Graindorge en Jos De Man

VERRECHTSING VAN DE STAAT?

DE ARBEIDEASSTAIJD VANDAAG

$\mathrm{m} \cdot \mathrm{m} \cdot \mathrm{v}$. Luclen Vannespen (VTR-Machelen) e.a.

WEGEN NAAA ZELFBEHËER

VERKRACHTING, SEXUALITEIT EN FEMINISME

m.m.v. Moniek Darge, en Bob Carlier

ALTERNATIEVEN TEN AANZIEN VAN HET STRAFRECHT

m.m.v. Herman Bianchi, Jef Vermassen C. Eliaerts

MOGELIJIKHEDEN OM LELF WERK TE CREEEREN

M.m, $\mathrm{Y}$ Kollektief Rampenplan Bittard, Geitenkollektief Alken en met vertoning f $11 \mathrm{~m}$ : 'Wacht niet te lang op de bazen'

MACHT

im.m.v. Leo Aposte1, Leopold Flam

THEOAETISCHE INLEIDING TOT DE DISCUSSIE OVER DE (AFSCHAFFING?) VAN HET WELLI INSWERK.

Alle lezingen starten om 20h, hetzij in de Valk, Tienseseraat 4I, Leuven Stuc, Van Evenstraat $2 \mathrm{~d}$, Leuven Aud. Vesalius, Van Evenstr. Ze Leuven Organisatie: Onkruit, Anarchistisch Kollektief Leuven, Radicale Criminologen Verdere Inlichtingen: Onkruit, Postbus 62, Leuven 3

v.U. Lieven Vanderstock, Parkstraat 197, Leuven
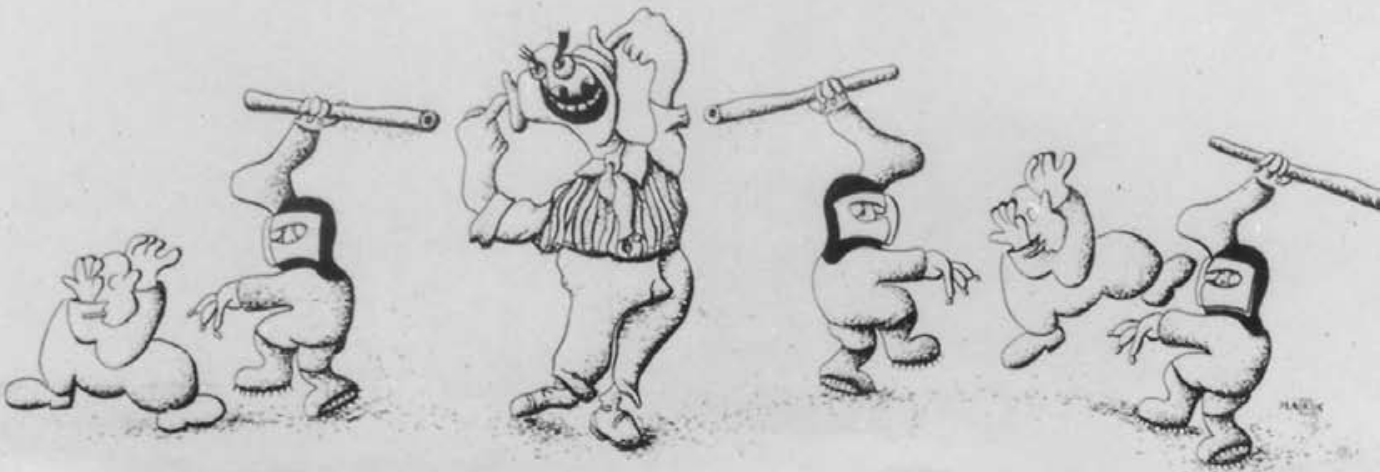
wenbeweging. Sommige radicale feministen stelden dat een maatschappij gecontroleerd door vrouwen het alternatief moest zijn voor de huidige patriarchale maatschappij. Anarchofeministen echter waarschuwden voor dit model: staatscontrole is altijd onderdrukkend en brengt onherroepelijk nieuwe ongelijkheden met zich. De anarchie is de enige organisatievorm waardoor dit voorkomen kan worden.

Dé grootste vernieuwing binnen het anarchisme, zonder meer ook de meest originele, is het ecologisch anarchisme van Murray Bookchin. ${ }^{(27)}$ Deze stroming sluit net als de vorige twee aan bij een algemene trend inzake bezorgdheid over de leefwereld en de ideologie van het postmaterialisme. Bookchin vertrekt vanuit de natuur als een 'spiritueel mechanisme', dat alles ziet oplossen in een kosmisch 'één zijn'; hij beschouwt de natuur als krachtig, rationeel en bewust. Het menselijke bewustzijn is slechts een exponent van dit 'natuurlijke web', deze natuurlijke ordening. Al riekt dit naar determinisme, toch impliceert het enkel dat de ontwikkeling van het individu moet gezien worden in relatie met andere entiteiten.

Bookchin stelt dat de moderne technologie een nieuw stadium heeft gecreëerd in de geschiedenis. Het verleden werd gedomineerd door materiële schaarste, die het patriarchale model heeft voortgebracht, met privébezit, klassendominantie en de Staat als voornaamste kwalen. Er werd een repressieve moraal van ontkenning en schuld in stand gehouden. In traditionele termen wordt de natuur gezien als een middel om de schaarste te overwinnen door haar te domineren en uit te buiten. Zowel de mens als de natuur zijn slachtoffer van deze dominantie, in zoverre zelfs dat ze door ecologische rampen gedoemd zijn om uit te sterven. $\mathrm{Nu}$ zijn we echter in het tijdperk van de 'postschaarste' terechtgekomen. ${ }^{(28)}$ "De bourgeois-samenleving revolutioneerde de productiemiddelen op een historisch ongekende schaal. Deze technologische revolutie, die zijn hoogtepunt vindt in de cybernetica, heeft de objectieve basis geschapen voor een wereld zonder klassenheerschappij, uitbuiting, zware lichamelijke arbeid of materieel gebrek.” (29) Deze postschaarste is volgens Bookchin dé vereiste om tot een vrije maatschappij in libertaire zin te komen. Hij stelt ons voor de keuze: ofwel evolueren we naar een anarchistische samenleving ofwel sterven we uit. Het anarchisme is voor hem de enige ideologie die eenheid kan scheppen in sociale diversiteit aangezien hij de natuur ziet als een organisch geheel, dat logisch in elkaar zit.

\section{De eindbalans}

Zowel het traditionele als het hedendaagse anarchisme wordt gedreven door dezelfde ideeën. Vrijheid, gelijkheid en een afkeer van elke vorm van autoriteit zijn gemeenschappelijke kenmerken. Er is enkel een accentverschuiving binnen deze drie. Het anarchisme is dan ook geen dode ideologie gebleven; het kreeg eind 19e-begin 20e eeuw een definitieve

Affiche van Onkruit, Anarchistisch Kollektief uit Leuven, 1982 
vorm. Al kwam het anarchisme in de jaren 1940-1970 in een ideologische en praktische impasse, een jongere generatie nam het voortouw over en nu leeft het anarchisme weer. Maar kunnen we wel een onderscheid maken tussen een 'traditioneel' en een 'hedendaags' anarchisme?

Ja, want er zijn wezenlijke verschillen op te merken. Het ecologische anarchisme met zijn volstrekt originele beschouwingen over de toekomstmaatschappij betekent een radicale vernieuwing van het anarchisme. Ook het anarchofeminisme is een innovatie geweest in de strijd tegen dominante verhoudingen. De beweging heeft ook een volstrekt ander gezicht gekregen. In het verleden eerder gericht op de arbeiders, was het anarchisme, met zijn eigen symbolen en uitzicht, een populaire zaak - getuige de propagandistische taal van de grote theoretici. De vernieuwde beweging heeft ook haar eigen tekens - het bekende anarchistische symbool is een creatie uit de jaren 1960 - en haar eigen publiek. Het anarchisme is in recentere tijden veeleer een zaak van intellectuelen geworden dan van de massa.

Neen, want de behandelde problemen zijn grosso modo onveranderd gebleven. Nog altijd wordt gestreden tegen het onrecht in de wereld, de structurele ongelijkheid van de klassen (in zoverre dit nog een term is die van toepassing is op ons maatschappelijk bestel) en nog altijd wordt een utopisch toekomstbeeld voorgehouden van een volledig egalitaire samenleving. De ideeën van de grootmeesters - Proudhon, Kropotkin en Bakoenin - komen in een modernere vorm terug, hetgeen maar evident kan zijn voor een ideologie die pretendeert dicht bij de massa te staan.

Dit artikel is gebaseerd op mijn licentiaatsverhandeling Hedendaags anarchisme in Nederland en Vlaanderen (1933-2000) aan de hand van de casus 'Pinksterlanddagen en het Terrein tot Vrijheidsbezinning', UGent, 2005, 225 p.

(1) Voor een vollediger definiëring van het anarchisme, onder meer aan de hand van de verschillende denkers (Proudhon, Bakoenin, Kropotkin, Malatesta enz.) en de verschillende stromingen, verwijs ik naar P. MARSHALL, Demanding the Impossible: A History of Anarchism, Londen: Fontana Press, 1992, $768 \mathrm{p}$.

(2) H. DE VOS, Geschiedenis van het socialisme in Nederland in het kader van zijn tijd, Baarn: Het Wereldvenster, 1976, I, p. 43-44.

(3) A. DE JONG, Van Christen tot anarchist en ander werk van F. Domela Nieuwenhuis, Utrecht: A.W. Bruna \& Zoon, 1970, 232 p.

(4) Beweren dat het anarchisme van Domela Nieuwenhuis dé Nederlandse variant is, zou onrecht doen aan de reële situatie. Het anarchisme in Nederland was onderhavig aan geografische - met een 'authentieker' anarchisme in het arme noorden, door de grote economische verschillen met het rijke Holland - en ideologische verschillen, zoals het prominente christenanarchisme (met Kropotkin als belangrijkste ideoloog).

(5) Anarchisme in Vlaanderen: J. MOULAERT, Rood en Zwart: de anarchistische beweging in Belgie (1880-1914), Leuven: Davidsfonds, 1995, 462 p.

(6) F. BOENDERS, A. LEHNING, P. AVRICH, e.a., De volle vrijheid: ideologie en geschiedenis van het anarchisme, Brussel: Manteau, 1978, p. 147.

(7) s.n., L'anarchisme à la une. In: L'anarchisme à la une, tentoonstellingsbrochure, Mons, 2005, p. 2. 
(8) Archief Appelscha, Pamflet van de Vrije Jeugd, 1924.

(9) Meer over de vroegste geschiedenis van de Pinksterlanddagen: A HAZEKAMP \& R. HURRELBRINCK, Kwaadwillige bedoelingen van die anarchistische elementen, de geschiedenis van de PL (1924-1940). In: bijlage bij Buiten de Orde zomer 2003, Tilburg: Vrije Bond, 2003, p. 5-10.

(10) Recht voor Allen, 1983, nr. 3, themanummer PL 50 jaar, p. 9.

(11) Recht voor Allen, 1983, themanummer PL 50 jaar, p. 9.

(12) De PL vinden tot op heden plaats in het Friese stadje Appelscha, op het terrein Tot Vrijheidsbezinning. Voor een uitvoeriger overzicht van de programmapunten op deze bijeenkomsten, verwijs ik naar mijn licentiaatsverhandeling: A. FAES, Hedendaags anarchisme in Nederland en Vlaanderen (1933-2000), UGent, licentiaatsverhandeling, 2005, p. 59-172.

(13) D. GUÉRIN, Het anarchisme, Amsterdam: Van Gennep, 1979, p. 113.

(14) A. HAZEKAMP, Temidden van het bruutste geweld. Het verzet van Nederlandse anarchisten tijdens de Tweede Wereldoorlog. In: Reader PL 2004, 30 mei 2004, p. 6-7.

(15) Een diepgaand onderzoek over de beweging Provo heb ik niet in mijn licentiaatsverhandeling opgenomen. Voor een analyse van het fenomeen Provo, verwijs ik naar het uitstekend werk van N. PAS, Imaazje: de verbeelding van Provo (1965-1967), Amsterdam: Wereldbibliotheek, 2003, 463 p.

(16) J. VERSCHUEREN, Plaats voor de homo ludens! Vlaamse provo's als nieuwe sociale beweging in een ruimtelijk wereld-systeem-analytisch perspectief, UGent, licentiaatsverhandeling, 2003, p. 101.

(17) R. VAN DUYN, Het witte gevaar: een vademekum voor provoos, Amsterdam: Meulenhoff, 1967, p. 17.

(18) Archief Appelscha, Congresbundel PL 70, 1970, $70 \mathrm{p}$.

(19) Onder meer de armoede van de noorderlingen, die zij in juxtapositie stelden met het rijke westen, met de provincie Holland, speelde hierin mee.

(20) Het probleem met anarchistische overkoepelende organen is dat het anarchisme autoriteit afkeurt; de interpretatie van vele anarchisten is dan ook dat elke anarchistische structuur paradoxaal genoeg structuurloos moet zijn. De clash tussen twee stromingen binnen het anarchisme, structuralisten tegen (wat we hier noemen) chaotici, zorgde er (onder meer) voor dat al deze pogingen dode letter bleven.
(21) De drie mannen kenden echter een andere evolutie tot het anarchisme. Domela Nieuwenhuis breekt met de Kerk en wordt anarchist, De Ligt is eerst religieus anarchist en Schermerhorn blijft predikant.

(22) A.L. CONSTANDSE, F. Domela Nieuwenhuis en het anarchisme in Nederland. In: F. BOENDERS, A. LEHNING, P.AVRICH, e.a., De volle vrijheid: ideologie en geschiedenis van het anarchisme, Brussel: Manteau, 1978. p. 118. Constandse vermeldt nog 'kolonialisering' als bepalende factor voor het anarchisme van Domela Nieuwenhuis. Nuancering is echter vereist.

(23) P. MARSHALL, Demanding the Impossible [...], p. 484. Eigen vertaling.

(24) Voor uitgebreide biografieën: P. J. MEERTENS, Biografisch woordenboek van het socialisme en de arbeidersbeweging in Nederland, Amsterdam: IISG, 1986, IX delen. Online te consulteren op http://www.iisg.nl/bwsa/index.html

(25) G. WOODCOCK, Anarchism: A History of Libertarian Ideas and Movements, Harmondsworth: Penguin books, 1977, p. 462.

(26) L. VAN HEERENTALS, Totaalweigeren in Belgie,, Gent: LSG, 1987, p. 1.

(27) M. BOOKCHIN, Ekologie en anarchisme, Utrecht: AK Utrecht, 1977, 130 p.

(28) Dit is tevens de titel van zijn meest invloedrijke essay, Post-Scarcity Anarchism, zoals opgenomen in M. BOOKCHIN, Ekologie en anarchisme [...], p. 105-126.

(29) M. BOOKCHIN, Ekologie en anarchisme [...], p. 105; P. MARSHALL, Demanding the Impossible [...], p. 609. Post-schaarste is niet hetzelfde als ongebreidelde overvloed, maar is eerder een voldoende technologische ontwikkeling die het individu in staat stelt om zijn noden autonoom te vervullen. 